\title{
ORIGINS, PHYLOGENIES AND RELATIONSHIPS IN THE FUNGAL KINGDOM
}

\author{
Á. SZÉCSI \\ Department of Plant Pathology, Plant Protection Institute, Hungarian Academy of Sciences, Budapest, \\ Hungary
}

The "true" fungi have been referred to as the Kingdom Fungi, the Kingdom Eumyceteae, or the Eumycota [1]. The fungi are eukaryotic organisms, characterized by: (i) a diversity of microbodies; (ii) cell walls that have a great similarity of architecture; (iii) hyphae that have a major chitin component, extended apically, and divide by centripetal invagination of the plasma membrane; (iv) lomasomes: sponge-like intumescences seen on the inside of the cell wall; (v) complete absence of the Golgi organelle in the terrestrial assemblages (zygomycetes, ascomycetes, and basidiomycetes) and some of the aquatic taxa; and (vi) nuclei in which most, if not all, gene products involved in mitosis probably have higher eukaryotic paramologues but which, in other ways, are exceptional [2]. Fungi are reproducing sexually or asexually, the diploid phase generally short-lived. Fungi parasitize a wide range of plants, animals, and other fungi [3].

The number of known species of fungi is about 70,000, but species of the fungal world are conservatively estimated to be 1.5 million [4]. The fungi are of great consequence agronomically, bioindustrially, medically, and biologically. In spite of their importance, their taxonomic inventory is poor. In addition, very little is known about the phylogeny and evolution of fungi and about the correlations between these and other organisms [1].

Sexual and asexual reproductive structures have provided important phenotypic characters to measure relatedness and evolutionary affinities among fungi. If they lose these structures, accurate taxonomic assignment is quite difficult.

To date, phylogenetic speculations and taxonomies for the fungi have been based mainly on analyses of morphological data sets. In the $1980 \mathrm{~s}$, development of molecular biological techniques (DNA:DNA hybridization, DNA fingerprinting, nucleic acid sequencing, isozyme analysis), proliferation of high performance computers, and improvement of molecular evolutionary analysis programs have extended studies of relatedness, phylogeny, and evolution of organisms, including fungi, at the molecular level [5-8]. Nucleic acid characters, as genotypic characters, are ubiquitous and are not dependent on the expression of reproductive structures. Nuclear DNA base composition 
and nuclear DNA relatedness, as nucleic acids characters resolve only to the genetic sibling species level [5].

Ribosomal RNA sequence comparisons, as a nucleic acid character, offer a means for estimating more distant relationships [9]. In recent years, molecular phylogenetic analysis of the fungi shifted to the small (18S) and large (23S to 28S) subunit rRNAs. Phylogenetic analysis among distantly related taxa, using 18S rRNA gene sequences, has contributed to well-resolved and statistically supported conclusions. In the early 1990s, such an approach has steered fungal taxonomy towards fungal molecular systematics [1017]. Thus, studies on fungal phylogeny and evolution have entered a new era.

Among earlier phylogenetic speculations concerning the fungi and related organisms that have been made during the past ten years, Cavalier-Smith [1] provided a framework for a taxonomic system and phylogeny for the fungal kingdom. His system included only the Chytridiomycetes, Zygomycetes, Ascomycetes, and Basidiomycetes in the Kingdom Fungi. These four fungal groups are characterized by chitinous cell wall and the alpha-aminoadipic acid (AAA) lysine biosynthetic pathway. The Oomycetes, Hyphochytrids, Labyrinthulida, Thraustochytrids, and slime molds, which are cellulosic and have the diaminopimelic acid (DAP) lysine biosynthetic pathway, are excluded from the Fungi. The former four major groups have been accommodated in the Pseudofungi and the latter in the slime moulds in the kingdom Protozoa [18]. He concluded that all major eufungal taxa, e.g., the Endomycota, Ascomycota, and Basidiomycota, evolved from the Entomophthorales from a chytridiomycete ancestor by loss of cilia (flagella). Molecular phylogenetic analysis [19, 20] confirmed that the chytrids were true fungi and the true fungi, the ascomycetes, the basidiomycetes, the zygomycetes, and the chytridiomycetes, formed a monophyletic group, distinguished from slime molds and the oomycetes. On the basis of $18 \mathrm{~S}$ rRNA sequence analysis, Hendriks et al. [21] indicated that the red algae and the higher fungi did not possess a common ancestor. Wainright et al. [22] suggested that animals and fungi share a unique evolutionary history and that their last common ancestor was a flagellated protist similar to extant choanoflagellates. According to the molecular evidence, the fungi may have originated from protozoan ancestors before the Kingdoms Animalia and Plantae split [23].

Berbee and Taylor [11] calculated that the three main fungal phyla diverged from the Chytridiomycota approximately $550 \mathrm{Myr}$ ago, that the Ascomycota/Basidiomycota split occurred at about $400 \mathrm{Myr}$ ago after plants invaded the land, and that many ascomycetous yeasts and moulds (e.g. Eurotiales) evolved after the origin of angiosperms in the last $200 \mathrm{Myr}$. These results are broadly supported by fossil evidence, the main difference being that remains of Ascomycota go back to the Silurian (c. 440 Myr ago) while the oldest definite Basidiomycota occurred at about $380 \mathrm{Myr}$ ago [24].

Data of the latest molecular phylogenetic analysis, using 18S rDNA sequence divergence, shows that a monophyletic kingdom for the Fungi contains the Chytridiomycetes and the Zygomycetes as lower fungi, and the Ascomycetes and Basidiomycetes as higher fungi. They suggest great phylogenetic divergence among the chytrids and the entomophthoralean fungi of the lower fungi and loss of flagella within several lineages of the lower fungi. On the other hand, the molecular and morphological data set clearly indicate existence of two monophyletic Divisions, Ascomycota and Basidiomycota. The former comprises the Archiascomycetes, as a new concept, the 
Hemiascomycetes (ascomycetous yeast), and the Euascomycetes, whereas the latter contains the Ustilaginales smut (or smut fungi), the simple septate Basidiomycetes, including most of the basidiomycetous yeasts, and the Hymenomycetes. Analyses of more taxa within these lineages and more sequence data are required to elucidate evolutionary relationships among the fungi, from the lower to higher fungi, in the light of the extensive fungal species diversity that has been revealed to date [13].

The other organisms previously regarded as "fungi" belong to Kingdom Protista, which for phylogenetic reasons should be divided into four separate kingdoms: Archeozoa, Euglenozoa, Protozoa, and Chromista [18].

In Kingdom Euglenozoa we find the Acrasida - a group of cellular slime moulds. Kingdom Protozoa contains two independent lineages of fungus-like organisms. One is phylum Mycetozoa encompassing class Myxogastrea (the true slime molds) and the small classes Dictyostelea (cellular slime moulds differ from Acrasida) and Protostelea. The other is the enigmatic phylum Plasmodiophoromycota which probably links with the Ciliophora in the alveolates. In Kingdom Chromista we also find two independent lineages. One leads to division Labyrinthomorpha comprising slime mould-like organisms. The other is the division Pseudofungi with the two classes Oomycetes and Hyphochytridiomycetes. Its closest relatives are probably yellow-green algae in Xanthophyta (25).

Out of the proposed classifications of higher categories including fungi and fungus-like organisms we cite the following [26]:

\section{PROTOZOA}

Acrasiomycota

Dictyosteliomycota

Myxomycota

Myxomycetes

Protosteliomycetes

Plasmodiophoromycota

\section{CHROMISTA}

Hyphochytriomycota

Labyrinthulomycota

Oomycota

\section{FUNGI}

Ascomycota

Basidiomycota

Basidiomycetes

Teliomycetes

Ustomycetes

Chytridiomycota

Zygomycota

Trychomycetes 


\section{Zygomycetes}

The Deuteromycota (Mitosporic fungi) is not accepted as formal taxonomic category in this proposed classification; they are not a monophyletic unit, but are fungi which have either lost a sexual phase or which are anamorphs of other phyla (mainly Ascomycota, some Basidiomycota). Of the three kingdoms (Chromista, Fungi, Protozoa) only Fungi consist exclusively of fungi; the Chromista and Protozoa mainly comprise non-fungal phyla. Some authors unite the Chromista and Protozoa into a single highly polyphyletic Kingdom Protoctista (syn. Protista), but that conclusion is not supported by molecular, biochemical, and other evidence. Cavalier-Smith [18] and Corliss [27] both retain Chromista and Protozoa as separate kingdoms.

\section{REFERENCES}

1. Cavalier-Smith,T.: The origin of fungi and pseudofungi. In Rayner,A.D.H., Brasier,C.M., Moore,D. (eds): Evolutionary Biology of the Fungi. Cambridge University Press, Cambridge. 1987. pp. 339-353.

2. Moore,R.T.: Evolutionary trends in the fungi. In Roberts,D.McL., Sharp,P., Alderson,G., Collins,M. (eds): Evolution of Microbial Life. Cambridge University Press, Cambridge. 1996. pp. 206-224.

3. Gee,H.: Mycological mystery tour. Nature 375, 276 (1995).

4. Hawksworth,D.L., Rossman,A.Y.: Where are all the undescribed fungi? Phytopathology 87, 888 (1997).

5. Bruns,T.D., White,T.J., Taylor,J.W.: Fungal molecular systematics. Annu Rev Ecol Syst 22, 525 (1991).

6. Hibbett,D.S.: Ribosomal RNA and fungal systematics. Trans Mycol Soc Japan 33, 533 (1992).

7. Foster,L.M., Kozak,K.R., Loftus,M.G., Stevens,J.J., Ross,I.K.: The polymerase chain reaction and its application to filamentous fungi. Mycol Res 97, 769 (1993).

8. Kurtzman,C.P.: Molecular taxonomy of the yeasts. Yeast 10, 1727 (1994).

9. Olsen,G.J., Woese,C.R.: Ribosomal RNA: a key to phylogeny. FASEB J 7, 113 (1993).

10. Bruns,T.D., Vilgalys,R., Barns,S.M., Gonzalez,D., Hibbett,D.S., Lane,D.J., Simon,L., Stickel,S., Szaro,T.M., Weisburg,W.G., Sogin,M.L.: Evolutionary relationship within the fungi: Analyses of nuclear small subunit rRNA sequences. Mol Phylogenet Evol 1, 231 (1992).

11. Berbee,M.L., Taylor,J.W.: Dating the evolutionary radiations of the true fungi. Can J Bot 71, 1114 (1993).

12. Bresinsky,A.: Abstammung, Phylogenie und Verwandtschaft im Pilzreich. Z Mykol 62, 147 (1996).

13. Sugiyama,J., Nagahama,T., Nishida,H.: Fungal diversity and phylogeny with emphasis on $18 \mathrm{~S}$ ribosomal DNA sequence divergence. In Colwell,R.R., Simidu,U., Ohwada,K. (eds): Microbial Diversity in Time and Space. Plenum Press, New York-London. 1996. pp. 41-51.

14. Holst-Jensen,A., Kohn,L.M., Schumacher,T.: Nuclear rDNA phylogeny of the Sclerotiniaceae. Mycologia 89, 885 (1997).

15. Mitchell,J.L, Roberts,P.J., Moss,S.T.: Sequence or structure? A short review on the application of nucleic acid sequence information to fungal taxonomy. Mycologist 9, 67 (1995).

16. Van de Peer,Y., De Wachter,R.: Investigation of fungal phylogeny on the basis of small ribosomal subunit RNA sequences. In Akkermans,A.D.L., Van Elsas,J.D., Bruijn,F.J. (eds): Molecular Microbial Ecology Manual. Kluwer Academic Publishers, the Netherlands. 1995. pp. 1-12.

17. Metzenberg,R.L.: Benefactor's lecture: The impact of molecular biology on mycology. Mycol Res 95, 9 (1991).

18. Cavalier-Smith,T.: Kingdom protozoa and its 18 phyla. Microbiol Rev 57, 953 (1993). 
19. Förster,H., Coffey,M.D., Elwood,H., Sogin,L.M.: Sequence analysis of the small subunit ribosomal RNAs of the three zoosporic fungi and implications for fungal evolution. Mycologia 82, 306 (1990).

20. Bowman,B.H., Taylor,J.W., Brownlee,A.G., Lee,J., Lu,S.D., White,T.J.: Molecular evolution of the fungi: Relationship of the Basidiomycetes, Ascomycetes, and Chytridiomycetes. Mol Biol Evol 9, 285 (1992).

21. Hendriks,L., DeBaere,R., Van de Peer,Y., Neffs,J., Goris,A., DeWachter,R.: The evolutionary position of the rodophyte Porphyra umbilicalis and the basidiomycete Leucosporidium scottii among other eucaryotes as deduced from complete sequences of small ribosomal subunit RNA. J Mol Evol 32, 167 (1991).

22. Wainright,P.O., Hinkle,G., Sogin,M.L., Stickel,S.K.: Monophyletic origin of the metazoa: an evolutionary link with fungi. Science 260, 340 (1993).

23. Gony,M., Li,W-H.: Molecular phylogeny of the kingdoms Animalia, Plantae, and Fungi. Mol Biol Evol 6, 109 (1989).

24. Taylor,J.W., Swann,E.C., Barbee,M.L.: Molecular evolution of ascomycete fungi: Phylogeny and conflict. In Hawksworth,D.L. (ed.): Ascomycete Systematics: Problems and Perspectives in the Nineties. Plenum Press, New York. 1994. pp. 201-212.

25. Hoiland,K.: Om soppenes moderne system - og om deres opprinnelse og tidlige evolusjon. Blyttia 53, 27 (1995).

26. Hawksworth,D.L., Kirk,P.M., Sutton,B.C., Pegler,D.N.: Ainsworth and Bisby's Dictionary of the Fungi. CAB International, UK. 1995. p. 616.

27. Corliss,J.O.: An interim utilitarian ("User-friendly") hierarchical classification of the protists. Acta Protozool. 33, 1 (1994) 